
\title{
25 Research Square \\ Effects of Persimmon Tannin-Aloe Vera Composite on Cytotoxic Activities, and Radioprotection Against $X$-rays Irradiated in HepG2 and L02 Cells
}

\section{Zhongmin WANG ( $\square$ zmwang@guet.edu.cn )}

Guilin University of Electronic Technology

\section{Xi QIAN}

Guilin University of Electronic Technology

Jinliang NING

Guilin University of Electronic Technology

\section{Chaoke QIN}

China Nonferrous Metal (Guilin) Geology for Mineral Co., Ltd

\section{Lin GAO}

Guilin University of Electronic Technology

$\mathrm{Na} \mathrm{HE}$

China Nonferrous Metal (Guilin) Geology for Mineral Co., Ltd

\section{Dahong LIN}

China Nonferrous Metal (Guilin) Geology for Mineral Co., Ltd

\section{Zhide ZHOU}

Guilin University of Electronic Technology

\section{Guiyin LI}

Guilin University of Electronic Technology

\section{Research Article}

Keywords: Persimmon tannin, Aloe vera, Human hepatic cells, Human hepatoma cells, Radioprotection effect

Posted Date: January 29th, 2021

DOl: https://doi.org/10.21203/rs.3.rs-152984/v1

License: (c) (1) This work is licensed under a Creative Commons Attribution 4.0 International License.

Read Full License 


\section{Abstract}

We investigated a persimmon tannin-Aloe vera composite powder (PT-A) for its capacity to protect against ionizing radiation. L02 cells and HepG2 cells were pretreated with PT-A (the mass ratio of persimmon tannin and Aloe vera is 2:1) or the single compounds at various concentrations, radiated with X-rays, and cell viability, apoptosis, and ROS production were analyzed by CCK-8, DCFH-DA staining, and Hoechst 33258 staining/flow cytometry, respectively. The optimal radiation dose and post-radiation incubation period were determined to be $8 \mathrm{~Gy}$ and $12 \mathrm{~h}$, respectively. The PT-A composite provided the best protection against ionizing radiation in both cell types. The apoptotic rate was the lowest at a PT-A concentration of $200 \mathrm{mg} / \mathrm{mL}$ in L02 cells $(4.32 \%, P<0.05)$, and at $100 \mathrm{mg} / \mathrm{mL}$ in HepG2 cells $(9.8 \%, P<$ 0.05). The activity of CCK-8 showed that the optimal radiation dose of L02 was $8 \mathrm{~Gy}$, and the cell activity was $71.72 \%\left(\mathrm{IC}_{50}=412.1 \mathrm{mg} / \mathrm{mL}\right)$. For HepG2, the optimal radiation dose was $8 \mathrm{~Gy}$, and the irradiation was $12 \mathrm{~h}$. The post cell activity was $62.372 \%\left(\mathrm{IC}_{50}=213.0 \mathrm{mg} / \mathrm{mL}\right)$. ROS production induced by radiation was the most effectively suppressed by $200 \mathrm{mg} / \mathrm{mL}$ PT-A in L02 cells, and by $100 \mathrm{mg} / \mathrm{mL}$ in HepG2 cells.

\section{Introduction}

With the progressively rapid research and societal developments, humans are increasingly exposed to ionizing radiation, and this trend is expected to continue and increase in future. Accordingly, the risk of diseases caused by ionizing radiation is increasing. Therefore, ionizing radiation treatment and protection programs have to be explored and developed [1].

The ionizing radiation pollution faced by Chinese residents mainly arises from natural and artificial ionizing radiation sources. Natural radiation mainly includes cosmic rays, terrestrial gamma rays, and helium, and accounts for $94 \%$ of the total annual radiation dose received by Chinese residents. According to the Nuclear and Radiation Safety report of the United Nations Scientific Committee on the Effects of Atomic Radiation, the global and individual average effective natural ionizing radiation doses for Chinese residents are $2.4 \mathrm{mSv}$ and $3.1 \mathrm{mSv}$, respectively [2]. In addition, radiation from artificial sources is growing rapidly, mainly because of developments in technology and nuclear science. In China, ionizing radiation technology and nuclear science began in the early days of the founding of the People's Republic of China and have since penetrated into medical, military, energy, and other industrial fields, and even into daily life, for example, in subway security and alarm systems $[3,4]$. The effective dose of personal radiation caused by artificial ionizing radiation and the average effective dose in Chinese residents are approximately $0.6 \mathrm{mSv}$ and $0.2 \mathrm{mSv}$, respectively. Medical diagnostic tests are the number one source of effective radiation in humans, and many advanced medical detection and treatment methods rely on ionizing radiation. In future, the use of ionizing radiation technology in the medical field is expected to increase, which will lead to an increase in ionizing radiation pollution. While natural radiation has existed forever, artificial radiation doses currently are on par with or even exceed natural radiation doses. Given the severity of ionizing radiation pollution and the related health risks, it is urgent to explore and develop methods to protect against ionizing radiation pollution. 
Anti-radiation agents are divided into non-natural and natural agents. Non-natural agents, including sulfhydryl compounds, nitroxide, dibenzimidazole, and superoxide dismutase, can have significant side effects and unstable treatment effects, and are relatively expensive. Natural radioprotective agents include vitamins, melatonin, flavonoids, and herbaceous and medicinal plants [5]. They reduce or eliminate the harm of ionizing radiation by blocking the harmful reactions caused by free radicals generated by radiation, reducing DNA damage, and inhibiting apoptosis .

Tannin is a polyphenolic compound widely found in plant materials such as persimmon fruits, tea leaves, ginkgo leaves, and grape seeds. It has a complex polyphenolic hydroxyl structure and is soluble in water and some organic solutions. Tannin has proven useful for the prevention and treatment of ionizing radiation pollution $[6,7]$. Sunan et al. reported that tannin effectively improved the survival of human megakaryocytes exposed to $10 \mathrm{~Gy}$ of $60 \mathrm{Co}$ y-rays by decreasing the production of reactive oxygen species (ROS) and suppressing apoptosis [8]. China is the largest persimmon producer globally, and Guangxi produces the most persimmons in China $[9,10]$. To ensure that most persimmons can mature normally, some green persimmons are removed; however, this results in substantial losses for persimmon farmers. Green persimmons are rich in tannin [11], and therefore, could be used as a source of tannin. Tannin has proven useful for the prevention and treatment of ionizing radiation pollution [12].

Aloe vera is comprises more than 70 components, including anthraquinones, vitamins, nonessential and essential amino acids, and inorganic compounds [13]. It is thought that Aloe vera can ameliorate radiation events on the epidermis and dermis owing to its ability to promote wound healing by increasing wound oxygenation and thus, minimize the amount of dead tissue. Thus, it might be useful to counteract the adverse effects of radiation therapy.

Persimmon tannin and Aloe vera are found as anti-radiation agents to protect against ionizing radiation. However, radiation resistance of the persimmon tannin-Aloe vera composite remains inconclusive. In this paper, a persimmon tannin- Aloe vera composite powder (PT-A) for its capacity to protect against ionizing radiation was investigated. Human hepatic cells (L02) and Human hepatoma cells (HepG2) are commonly used in in-vitro studies on radiation and to determine radioprotective effects of anti-ionizing radiation materials $[14,15]$. Use these two cells as model cells to protect against ionizing radiation, cell viability, apoptosis, and ROS production were analyzed by CCK-8, DCFH-DA staining, and Hoechst 33258 staining/flow cytometry and cell viability, apoptosis.

\section{Materials And Methods}

\section{Experimental reagents, and instruments}

Persimmons were provided by Guangxi Huikun Company (Guangxi, China). Freeze-dried Aloe vera powder was provided by Guangdong Yuanlv Biological Engineering (Guangdong, China). Low-endotoxin fetal bovine serum (FBS) was provided by Zhejiang Tianhang Biotechnology (Zhejiang, China), highglucose DMEM was purchased from Thermo Fisher Scientific (Waltham, MA), trypsin from Beijing 
Solarbio Science \& Technology, and 2',7'-dichlorfluorescein diacetate (DCFH-DA) from Sigma-Aldrich (St. Louis, MO). All other chemical reagents were biochemical grade. The TU-1901 UV-visible spectrophotometer was from Beijing Persee General Instrument (Beijing, China), and the flow cytometer was from Beckman Coulter (Brea, CA, USA)

Human hepatic cells (L02) and Human hepatoma cells (HepG2) were purchased from the cell bank of the Chinese Academy of Sciences and that of Central South University, respectively.

\section{Cell culture}

Cell culture was synthesized according to the glutaraldehyde crosslinking method described by our previous work with minor modifications Frozen L02 and HepG2 cells were quickly thawed in warm water bath at $37^{\circ} \mathrm{C}$, collected by centrifugation, and resuspended in fresh medium $[16,17,18]$. The thawed culture solution was aspirated (dropped into the thawed culture solution) into a $15 \mathrm{~mL}$ tube; the prepared fetal bovine serum content was $10 \% .2 \mathrm{~mL}$ of fresh high-sugar DMEM medium, the frozen stock solution remaining in the L02 and HepG2 cells, was removed by centrifugation. The old medium in the centrifuge tube was removed after centrifugation, and the cells in the bottom of the centrifuge tube were blown upward by fresh medium to prevent further gathering. After the cell suspension was added to a $25 \mathrm{~cm}^{2}$ cell culture flask, the flask was placed in a thermostatic cell culture incubator at a constant temperature of $37^{\circ} \mathrm{C}$ and a constant carbon dioxide content of $5 \%$. The cells were cultured until the cell growth area accounted for $80-90 \%$ of the bottom of the cell bottle; Afterward, the old medium was removed and trypsin-digested cells were added, and then the cells were blown downward by adding fresh medium, followed by centrifugation. The subsequent steps were the same as those described previously, and a heavy cell culture will result. The suspended cell fluid was added to two new cell culture flasks to complete the cell passage, and the cells were cultured repeatedly until the cell volume reached $80-90 \%$ [19].

\section{Determination of the active ingredient in persimmon powder}

A $10 \%$ Lowry solution and $7.5 \%$ sodium carbonate solution were prepared. Zero, 1, 2, 3, 4, or $5 \mathrm{~mL}$ of a of $1000 \mathrm{mg} / \mathrm{mL}$ gallic acid standard solution was added to a $100-\mathrm{mL}$ flask. Persimmon powder $(0.1 \mathrm{~g})$ was dissolved in $100 \mathrm{~mL}$ of ultrapure water and $2.5 \mathrm{~mL}$ of this solution was pipetted into a $50-\mathrm{mL}$ flask, and ultrapure water was added up to the mark line to prepare the test solution. The absorbance was measured using an UV spectrophotometer to obtain a standard curve. The tannin content in the persimmon powder was calculated to be $25.00 \%$ based on the prepared gallic acid standard curve $(\mathrm{y}=$ $\left.0.01194 x+0.0033, R^{2}=0.9996\right)$. The content of persimmon tannin can be calculated according to the standard linear equation of gallic acid. According to the calculation, the persimmon tannin content in the persimmon freeze-dried powder used in the experiment was $25.00 \%$. 


\section{Determination of the active ingredient in aloe freeze-dried powder}

The content of the active ingredient in the aloe lyophilized powder was determined by measuring the $O$ acetyl content by spectrophotometry and preparing a standard curve, as described previously [20, 21]. The standard curve equation was as follows: $y=2.2633 x+0.0125, R^{2}=0.9995$. Using this equation, the O-acetyl content in the aloe freeze-dried powder was calculated to be $0.60 \%$.

\section{Preparation of persimmon tannin-Aloe vera composite (PT-} A)

The PT-A composite material was prepared considering the active ingredient contents in the two source material. First, composite PT-A with a mass ratio of the $\mathrm{O}$-acetyl group in persimmon powder to Aloe vera powder of 2:1 was produced through crosslinking. The precipitated PT-composite material was collected, completely dried in an oven at $50^{\circ} \mathrm{C}$ for $6 \mathrm{~h}$, and pulverized to obtain a powder.

\section{CCK-8 assay of the effect of PT-A}

The metabolic activity of cells after irradiation was measured by a CCK-8 assay [22, 23]. After synchronization of L02 cells, the medium was removed, and $90 \mathrm{~mL}$ of fresh high-glucose medium containing $10 \%$ FBS and $10 \mathrm{~mL}$ of PT-A (PT, Aloe vera) at $0,50,100,200,400$, and $800 \mathrm{mg} / \mathrm{mL}$ was added. Subgroups with concentrations of $0,50,100,200,400$, and $800 \mathrm{mg} / \mathrm{mL}$ were created. In addition, the blank group was set to medium only and no cells were seeded. After $24 \mathrm{~h}$ of culture, cells in all experimental groups were exposed to X-ray doses of 0 (control), 4, 8, 12, 16, and $20 \mathrm{~Gy}$. At 12 or $24 \mathrm{~h}$ after irradiation, the medium was removed and the cells were gently washed thrice with PBS. Then, $10 \mathrm{~mL}$ of CCK-8 assay solution and $90 \mathrm{~mL}$ of high-glucose medium containing $10 \%$ fetal calf serum were added to each well. When the CCK-8 solution was completely activated after $3 \mathrm{~h}$, the absorbance at $490 \mathrm{~nm}$ was measured in each well. Cell viability was calculated using equation (1).

Cell vitality $(\%)=\left(\frac{O D_{\text {dug }}-O D_{\text {tlank }}}{O D_{\text {control }}-O D_{\text {blentk }}}\right) \times 100 \%$

\section{Hoechst 33258 staining for apoptosis detection}

Apoptosis was assayed by staining cells with the fluorescent dye Hoechst 33258 as reported [24, 25]. Synchronized L02 cells were treated with PT-A (PT, Aloe vera) at 0, 50, 100, 200, 400, or $800 \mathrm{mg} / \mathrm{mL}$. In addition, a blank control group with medium only was prepared. After $24 \mathrm{~h}$ of culture, the cells were exposed to $0 \mathrm{~Gy}$ or the optimal X-ray radiation dose. After $12 \mathrm{~h}$ of culture, the cell fixative solution was 
removed, and the cells were washed twice with PBS for 3 min. Finally, the cells were stained with $500 \mathrm{~mL}$ of Hoechst 33258 dye for 5 min. The dye was removed and the cells washed twice with PBS for 3 min. One drop of fluorescence quenching solution was added to each well, and the staining intensity was observed using an inverted fluorescence microscope at a magnification of $200^{\prime}$, and images were acquired.

\section{Flow cytometry for apoptosis detection}

Apoptosis or cell death commonly occurs in the body [26]. Moreover, apoptosis was evaluated using an Annexin V/FITC-PI apoptosis assay kit [27]. Synchronized L02 cells were treated with PT-A (PT, Aloe vera) at $0,50,100,200,400$, or $800 \mathrm{mg} / \mathrm{mL}$. In addition, a blank group with medium only was established. After $24 \mathrm{~h}$ of culture, the cells were exposed to $0 \mathrm{~Gy}$ or the optimal X-ray radiation dose. Then, PBS and $0.4 \mathrm{~mL}$ of Annexin $\mathrm{V}$ binding buffer was added to the cells $\left(1 \times 10^{6} \mathrm{cells} / \mathrm{mL}\right)$. Then, $5 \mathrm{~mL}$ of Annexin V-FITC was added to the cell suspension, the cells were removed and added to a flow tube, and apoptosis was detected by flow cytometry.

\section{Performance of PT-A in removing intracellular ROS}

Synchronized L02 cells were treated with PT-A at 0, 50, 100, 200, 400, or $800 \mathrm{mg} / \mathrm{mL}$. The old medium of each well was removed, six subgroups for different PT-A concentration with four parallel holes each were provided. After $24 \mathrm{~h}$ of incubation, the L02 cells were irradiated with an optimal dose of X-ray radiation. Meanwhile, the control group was set only for the medium and was not seeded. After being irradiated, the L02 cells were placed into the incubator for $12 \mathrm{~h}$ of cultivation. Then, the medium was removed and the cells washed twice with PBS for 3 min. Finally, the fluorescence intensity was measured in a microplate reader using $480 \mathrm{~nm}$ and $525 \mathrm{~nm}$ wavelengths, and was used to calculate the ROS content [28, 29].

In the same way, HepG2 cells was prepared according to the above method.

\section{Statistical analysis}

Each experiment was performed in triplicates. Data were expressed as the mean \pm standard deviation (SD). All data in this study were analyzed with the SPSS 10.0 software package. And a P-value $<0.05$ was considered statistically significant. All experiments were conducted in triplicate unless otherwise noted in the text.

\section{Results And Discussion}

\section{Active ingredient contents in PT-A composite}


The persimmon and aloe powders were mixed at an active ingredient mass ratio of 2:1. The absorbance of the PT-A solution was determined by UV spectrophotometry at $765 \mathrm{~nm}$ and $560 \mathrm{~nm}$. Using standard curves for gallic acid and $O$-acetyl, the tannin and $O$-acetyl contents in the PT-A composite were calculated as $1.15 \%$ and $0.57 \%$, respectively; thus, the ratio was close to $2: 1$, as expected.

\section{PT-A protect against ionizing radiation by CCK-8 assay}

The capacities of pure PT and Aloe vera and the PT-A composite to protect cells against ionizing radiation were evaluated by CCK-8 assay, using L02 and HepG2 cells. The cells were exposed to X-rays at a dose of $8 \mathrm{~Gy}$, and were incubated for $12 \mathrm{~h}$ after irradiation. As shown in Fig. 1A, the highest L02 cell activity was observed in the groups pretreated with PT, Aloe vera, or PT-A at $200 \mu \mathrm{g} / \mathrm{mL}$. Additionally, the protective effect of the composite was superior to that of the single compounds; when pretreated with PTA, the cells exhibited the strongest radiation resistance. In HepG2 cells, PT, Aloe vera, and PT-A showed the strongest ionizing radiation-protective effect at $100 \mu \mathrm{g} / \mathrm{mL}$, and the composite again had a better effect than the single compounds (Fig. 1B). Figure 2 shows the morphology of cells treated or not with PT, Aloe vera, or PT-A at $200 \mu \mathrm{g} / \mathrm{mL}$. As we can see in Fig. 2C\&F, the lowest amount of cell debris due to apoptosis was observed, which proved fewer apoptotic cells than the other groups. Therefore, PT-A composite was selected as the optimal composite material for further investigation.

\section{Determination of the optimal radiation dose and material concentration}

Next, we determined the viability of L02 and HepG2 cells under different X-ray radiation doses and various PT-A concentrations. The activity of L02 cells continuously decreased with increasing radiation dose, indicating that the activity of L02 cells was greatly affected by X-ray irradiation (Fig. 3A, B). At a dose of $20 \mathrm{~Gy}$, the activity of non-treated L02 cells was close to zero. With increasing PT-A concentration, L02 cell activity after 8-Gy radiation initially increased to reach a plateau at $200 \mu \mathrm{g} / \mathrm{mL}$, and then decreased. The viability of cells cultured for $12 \mathrm{~h}$ and $24 \mathrm{~h}$ after irradiation was compared; the viability of cells cultured for $12 \mathrm{~h}$ after irradiation was generally higher than that of cells cultured for $24 \mathrm{~h}$. The activity of HepG2 cells decreased with increasing radiation dose (Fig. 3C, D). When the X-ray radiation dose was $20 \mathrm{~Gy}$, the activity of non-treated HepG2 cells was less than $5 \%$, indicating that X-rays have a strong inhibitory effect on the activity of HepG2 cells. HepG2 cell activity after $8 \mathrm{~Gy}$ irradiation increased with increasing PT-A concentration from 0 to $100 \mu \mathrm{g} / \mathrm{mL}$, where it peaked, indicating the latter concentration was the most effective. Again, the viability of cells cultured for $12 \mathrm{~h}$ after irradiation was higher than that of cells cultured for $24 \mathrm{~h}$. Based on these experiments, a radiation dose of $8 \mathrm{~Gy}$ and irradiation for $12 \mathrm{~h}$ were selected as optimal experimental conditions and were used in subsequent experiments. When the dose of X-ray irradiation was $8 \mathrm{~Gy}, \mathrm{IC}_{50}$ was calculated to be $412.1 \mu \mathrm{g} / \mathrm{mL}$ for PT-A composite with L02 at $12 \mathrm{~h}$ incubation after irradiation. And $\mathrm{IC}_{50}$ was calculated to be $213.0 \mu \mathrm{g} / \mathrm{mL}$ for PT-A composite with HepG2 at $12 \mathrm{~h}$ incubation after $8 \mathrm{~Gy}$ X-ray irradiation [30].

\section{PT-A suppress apoptosis in L02 and HepG2 cells}


L02 and HepG2 cells were pretreated with different concentrations of the three test compounds, irradiated, and subjected to Hoechst 33258 fluorescence staining (Fig. 4) or flow cytometry (Fig. 5) for apoptosis analysis. As for L02 cells, the apoptotic rate was the lowest in the $200 \mu \mathrm{g} / \mathrm{mL}$ treatment groups (Figs. 4A, 5A). Upon radiation, the apoptotic cells containing apoptotic features such as nuclear shrinkage and chromatin condensation were observed. Compare with Fig. 4A.a $(50 \mu \mathrm{g} / \mathrm{mL})$ and Fig. 4A.c (800 $\mu \mathrm{g} / \mathrm{mL}$ ), the number of apoptotic cells kept less when the persimmon tannin concentration was 100 $\mu \mathrm{g} / \mathrm{mL}$ (Fig. 4A.b). Cells pretreated with PT-A had the lowest apoptotic rate, compared with cells pretreated with a single compound (Cells pretreated with PT or with Aloe vera). As we can see in Fig. 5A, cells pretreated with PT-A also has the lowest apoptosis rate among the groups. These findings indicated that PT-A effectively protected L02 cells from ionizing radiation. The composite provided optimal protection against ionizing radiation at $200 \mu \mathrm{g} / \mathrm{mL}$, which was consistent with the CCK-8 assay results. As for HepG2 cells, the apoptotic rate was the lowest in the $100 \mu \mathrm{g} / \mathrm{mL}$ treatment groups (Figs. 4B, 5B). From Fig. 4B, nuclear shrinkage and chromatin condensation were observed clearly, compare with Fig. 4B.a $(50 \mu \mathrm{g} / \mathrm{mL})$ and Fig. 4B.c $(800 \mu \mathrm{g} / \mathrm{mL})$, the number of apoptotic cells kept less when the persimmon tannin concentration was $200 \mu \mathrm{g} / \mathrm{mL}$ (Fig. 4B.b). Therefore the PT-A composite more effectively suppressed apoptosis than the single compounds, indicating it has a better anti-ionizing radiation effect. As we can see in Fig. 5B, cells pretreated with PT-A also has the lowest apoptosis rate among the groups. The composite had the best effect when used at a concentration of $100 \mu \mathrm{g} / \mathrm{mL}$, which was in line with the CCK-8 findings.

\section{PT-A suppresses ROS production}

ROS production in cells was measured by DCFH-DA fluorescence staining. X-ray irradiation at 8 Gy resulted in a significant increase in ROS in L02 cells compared to control cells (Fig. 6A). The fluorescence intensity in L02 cells treated with 50, 100, 200, 400, and $800 \mu \mathrm{g} / \mathrm{mL}$ PT-A was $69 \%, 60 \%, 36 \%, 55 \%$, and $59 \%$ that of non-pretreated cells, respectively ( $P<0.05 \mathrm{vs.} \mathrm{control} \mathrm{cells} \mathrm{for} \mathrm{all} \mathrm{treatments).} \mathrm{Among} \mathrm{the}$ experimental groups, the fluorescence intensity was the lowest in the $200 \mu \mathrm{g} / \mathrm{mL}$ group, indicating that at this concentration, PT-A is optimally effective in suppressing ROS production induced by radiation in L02 cells and provides the strongest protection against ionizing radiation.

Excessive intracellular ROS damages not only normal cells, but also cancer cells. Irradiating cancer cells with X-rays is one of the basic principles of radiotherapy. The ROS content was significantly increased in irradiated cells when compared with non-irradiated control cells (Fig. 6B). The DCFH-DA fluorescence intensities in the HepG2 cells treated with $50,100,200,400$, and $800 \mu \mathrm{g} / \mathrm{mL}$ PT-A was $69 \%, 60 \%, 36 \%$, $55 \%$, and $59 \%$ that of non-pretreated cells, respectively ( $P<0.05$ vs. control cells for all treatments), and the fluorescence intensity was the lowest in the $100 \mu \mathrm{g} / \mathrm{mL}$ group, indicating that at this concentration, PT-A is the most effective in suppressing radiation-induced ROS production in HepG2 cells. The results of this experiment indicated that one of the potential mechanisms of persimmon tannin in protecting against ionizing radiation is to suppress ROS production in response irradiation. Because of its polyphenolic hydroxyl structure, tannin can react with ROS. Further, the experimental results showed that PT-A had the strongest anti-ionizing radiation effect in normal liver cells, and did not eliminate ROS in 
liver cancer cells. Thus, ROS would still cause damage to cancer cells, which makes the composite useful in practical applications such as chemotherapy, because the therapeutic effect is ensured.

\section{Radioprotective mechanism of PT-A}

The PT-A composite contains reducing phenolic hydroxyl groups, which can react with ROS. Therefore, from the ROS removal experiment, it can be concluded that one potential mechanism underlying the antiionizing radiation effect of the composite is to remove excess ROS generated in response to irradiation, thus preventing a series of cellular events induced by the ROS and consequently avoiding damage caused by ROS peroxidation.

The above experiments showed that the radioprotective effect of the composite was stronger in normal cells than in cancer cells, and the PT-A concentration required for protecting normal cells from ionizing radiation $(200 \mu \mathrm{g} / \mathrm{mL})$ was higher than that required for protecting cancer cells $(100 \mu \mathrm{g} / \mathrm{mL})$. In addition, the ROS clearance rate was lower in cancer cells than in normal cells. The optimal PT-A concentration for ROS production suppression in normal cells was $200 \mu \mathrm{g} / \mathrm{mL}$, which was lower than that needed in cancer cells $(100 \mu \mathrm{g} / \mathrm{mL})$. In conclusion, the PT-A composite might protect normal cells from ionizing radiation in practical applications, and would not favor cancer cell growth. Therefore, it might be useful as a natural, harmless anti-ionizing radiation agent, and has various application prospects.

\section{Conclusions}

This study examined the ionizing radiation-protective effects of a PT-A composite (the mass ratio of persimmon tannin and Aloe vera was 2:1) in comparison with the single compounds (persimmon tannin or Aloe vera) in L02 and HepG2 cells. Cell viability, cell apoptosis, and radiation-induced intracellular ROS generation were analyzed by CCK-8, Hoechst 33258 staining/flow cytometry, and DCFH-DA assay, respectively for $12 \mathrm{~h}$ or $24 \mathrm{~h}$ incubation after radiation. X-ray irradiation at $8 \mathrm{~Gy}$ and a $12 \mathrm{~h}$ incubation after irradiation were deemed optimal experimental conditions. PT-A, was the most effective in suppressing apoptosis and ROS production when used at $200 \mu \mathrm{g} / \mathrm{mL}$ in L02 cells and at $100 \mu \mathrm{g} / \mathrm{mL}$ in HepG2 cells. By comparing normal cells with liver cancer cells, we can see that the persimmon tanninAloe vera composite has a good effect on ionizing radiation. The persimmon tannin-Aloe vera composite exertes its radiation protective action through increasing cell viability, reducing cell apoptosis and decreasing the ROS levels of X-ray exposure in cells. This study serves as a preliminary pre-clinical evaluation of persimmon tannin-Aloe vera composite for use for radiation protection in humans.

\section{Declarations}

\section{Conflicts of interest}

There are no conflicts of interest to declare. 


\section{Acknowledgments}

This work was supported by National Natural Science Foundation of China (Nos. 81760534 and 51961010), Guangxi Key Research and Development Program (Nos. Guike 2018 AB38016 and Guike AB16380278), the Natural Science Foundations of Guangxi Province (No. 2016GXNSFGA380001). We would like to thank Editage (www.editage.cn) for English language editing.

\section{References}

1. Burmeister, W. P. Structural changes in a cryo-cooled protein crystal owing to radiation damage. Acta Crystallogr D Biol Crystallogr. 56 (3), 328-341 (2010).

2. Candéias, S. M. et al. Low-dose radiation accelerates aging of the T-cell receptor repertoire in $\mathrm{CBA} / \mathrm{Ca}$ mice. Cell Mol Life Sci2017, 74 (23),1-13.

3. Zeng, M. et al. Review of nuclear power development in China: Environment analysis,historical stages, development status, problems and countermeasures.Renew. Sust. Energ. Rev.2016,13691383.

4. Sun, Y. et al. Influence mechanism of low-dose ionizing radiation on Escherichia coli DH5 a population based on plasma theory and system dynamics simulation. J ENVIRON RADIOACTIV. 151 (151), 185-192 (2016).

5. Bala, S., Chugh, N. A., Bansal, S. C., Garg, M. L. \& Koul, A. Radiomodulatory effects of Aloe vera on hepatic and renal tissues of X-ray irradiated mice. Mutat Res. 811, 1-15 (2018).

6. Chen, L., Liu, Y., Dong, L. \& Chu, X. Edaravone protects human peripheral blood lymphocytes from Yirradiation-induced apoptosis and DNA damage. Cell Stress \& Chaperones20 (2),289-295.

7. Chavan, Y. \& Singhal, R. S. Ultrasound-assisted extraction (UAE) of bioactives from arecanut (Areca catechu L.) and optimization study using response surface methodology. Innovative Food Science \& Emerging Technologies. 17, 106-113 (2013).

8. Chen, Z. et al. INF2 regulates oxidative stress-induced apoptosis in epidermal HaCaT cells by modulating the HIF1 signaling pathway. Biomed Pharmacother. 111, 151-161 (2019).

9. Zhang, Y., Zhu, W., Deng, X. Y., Peng, J. M. \& Li, C. M. Both non-covalent and covalent interactions were involved in the mechanism of detoxifying effects of persimmon tannin on Chinese cobra PLA2. Fitoterapia 2017, 120,41-51.

10. Wang, Z. M. et al. Equilibrium, kinetics and mechanism of $\mathrm{Au}(3+), \mathrm{Pd}(2+)$ and $\mathrm{Ag}(+)$ ions adsorption from aqueous solutions by graphene oxide functionalized persimmon tannin. Mater Sci Eng C Mater Biol Appl. 79, 227-236 (2017).

11. Zhou, Z. D., Huang, L. F., Wang, Y. \& Li, Z. M. GY, Biosorption of palladium(II) from aqueous solution by grafting chitosan on persimmon tannin extract. INT J BIOL MACROMOL. 77, 336-343 (2015).

12. Zhou, Z. D. et al. Extraction, purification and anti-radiation activity of persimmon tannin from Diospyros kaki L.f. Journal of Environmental Radioactivity2016, 162-163,182-188. 
13. Farrugia, C. E., Burke, E. S., Haley, M. E., Bedi, K. T. \& Gandhi, M. A. The use of aloe vera in cancer radiation: An updated comprehensive review. Complement Ther Clin Pract. 35, 126-130 (2019).

14. Gao, X. D. et al. Effects of N-trans-feruloyltyramine isolated from laba garlic on antioxidant, cytotoxic activities and H2O2-induced oxidative damage in HepG2 and L02 cells. Food Chem Toxicol. 130, 130-141 (2019).

15. Piman, P., Natthida, W. \& Kanjana, T. Structures of isothiocyanates attributed to reactive oxygen species generation and microtubule depolymerization in HepG2 cells. Biomed. Pharmacother. 101, 698-709 (2018).

16. Abernathy, L. M. et al. Soy Isoflavones Promote Radioprotection of Normal Lung Tissue by Inhibition of Radiation-Induced Activation of Macrophages and Neutrophils. J Thorac Oncol. 10 (12), 17031712 (2015).

17. Gao, X. D. et al. Effects of N-trans-feruloyltyramine isolated from laba garlic on antioxidant, cytotoxic activities and H2O2-induced oxidative damage in HepG2 and L02cells. Food Chem Toxicol. 130, 130-141 (2019).

18. Qian, X. et al. Protecting HaCaT cells from ionizing radiation using persimmon tannin-Aloe gel composite. Pharm Biol. 58 (1), 510-517 (2020).

19. Hillman, G. G. et al. Soy isoflavones radiosensitize lung cancer while mitigating normal tissue injury. Radiother Oncol. 101 (2), 329-336 (2011).

20. Nazeam, J. A., Gad, H. A., El-Hefnawy, H. M. \& Singab, A. B. Chromatographic separation and detection methods of Aloe arborescens Miller constituents: A systematic review. J Chromatogr B Analyt Technol Biomed Life Sci. 1058, 57-67 (2017).

21. Kumar, S. \& Kumar, R. Role of acemannan O-acetyl group in murine radioprotection. Carbohydr Polym. 207, 460-470 (2019).

22. Vázquez-León, P., Campos-Rodríguez, C., Gonzalez-Pliego, C. \& Miranda-Páez, A. Differential effects of cholecystokinin (CCK-8) microinjection into the ventrolateral and dorsolateral periaqueductal gray on anxiety models in Wistar rats. Horm Behav. 106, 105-111 (2018).

23. Wang, Z. et al. NEAT1 regulates neuroglial cell mediating Abeta clearance via the epigenetic regulation of endocytosis-related genes expression. Cell Mol Life Sci. 76 (15), 3005-3018 (2019).

24. Kabir, A. \& Suresh Kumar, G. Targeting of 1-Naphthyl acetyl spermine to DNA: A calorimetric and spectroscopic investigation. J CHEM THERMODYN. 94, 52-60 (2016).

25. Zhou, Y. et al. Multiplexed imaging detection of live cell intracellular changes in early apoptosis with aggregation-induced emission fluorogens. Sci. China Chem. 61 (8), 892-897 (2018).

26. Jakobczyk, H., Sciortino, F., Chevance, S., Gauffre, F. \& Troadec, M. B. Promises and limitations of nanoparticles in the era of cell therapy: Example with CD19-targeting chimeric antigen receptor (CAR)-modified T cells. International Journal of Pharmaceutics532 (2),813-824.

27. Nattaporn, B., Nijsiri, R., Chaisak, C. \& Wacharee, L. Ethyl acetate extract from Glycosmis parva leaf induces apoptosis and cell-cycle arrest by decreasing expression of COX-2 and altering BCL-2 family gene expression in human colorectal cancer HT-29 cells.Pharmaceutical Biology2015, 53 (4),540-7. 
28. Martins, E. N. et al. Protective effect of Melissa officinalis aqueous extract against Mn-induced oxidative stress in chronically exposed mice. Brain Res Bull. 87 (1), 74-79 (2012).

29. Zhang, Y. et al. ROS-mediated miR-21-5p regulates the proliferation and apoptosis of $\mathrm{Cr}(\mathrm{VI})$-exposed L02 hepatocytes via targeting PDCD4. Ecotoxicol Environ Saf. 191, 110160 (2020).

30. Ma, X. et al. MicroRNA-195 regulates docetaxel resistance by targeting clusterin in prostate cancer. Biomed. Pharmacother. 99, 445-450 (2018).

\section{Figures}
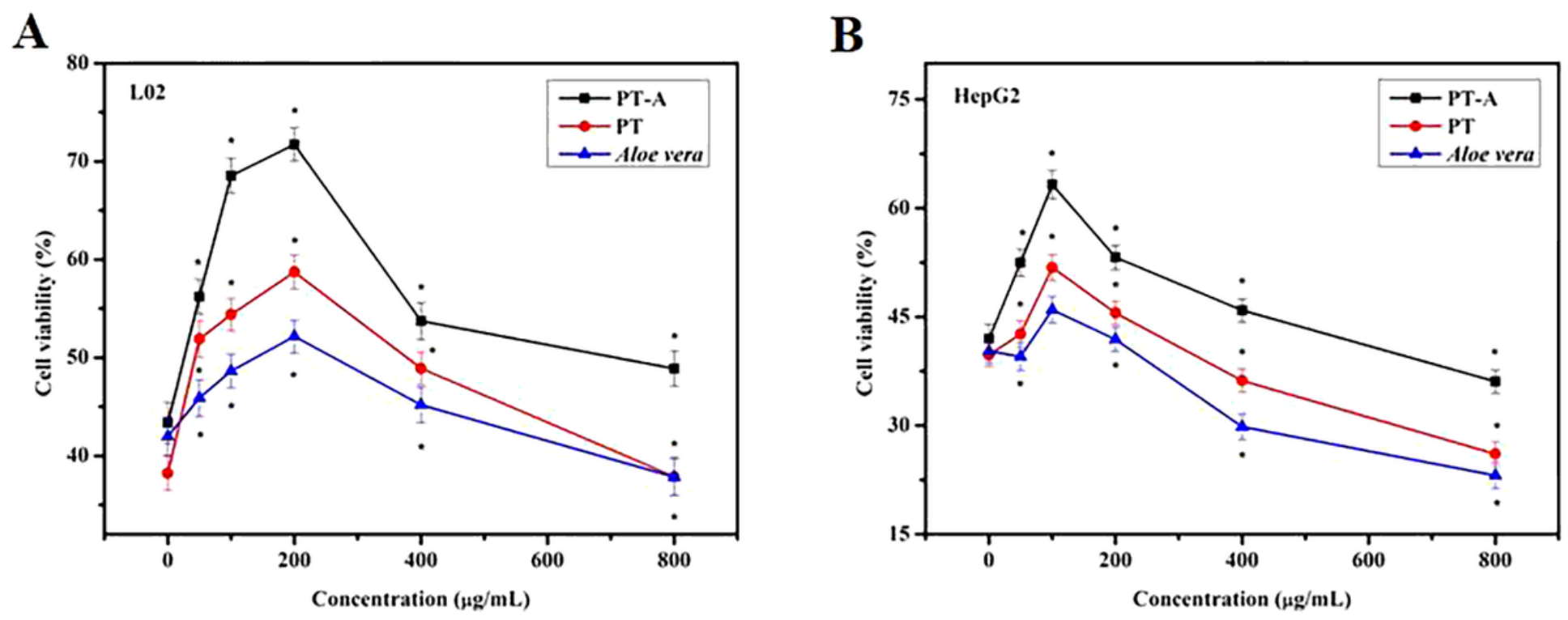

\section{Figure 1}

CCK-8 assay the capacity against ionizing radiation of different component materials (A for L02 cells, B for HepG2 cells). The cells were exposed to X-rays at a dose of $8 \mathrm{~Gy}$, and were incubated for $12 \mathrm{~h}$ after irradiation. 

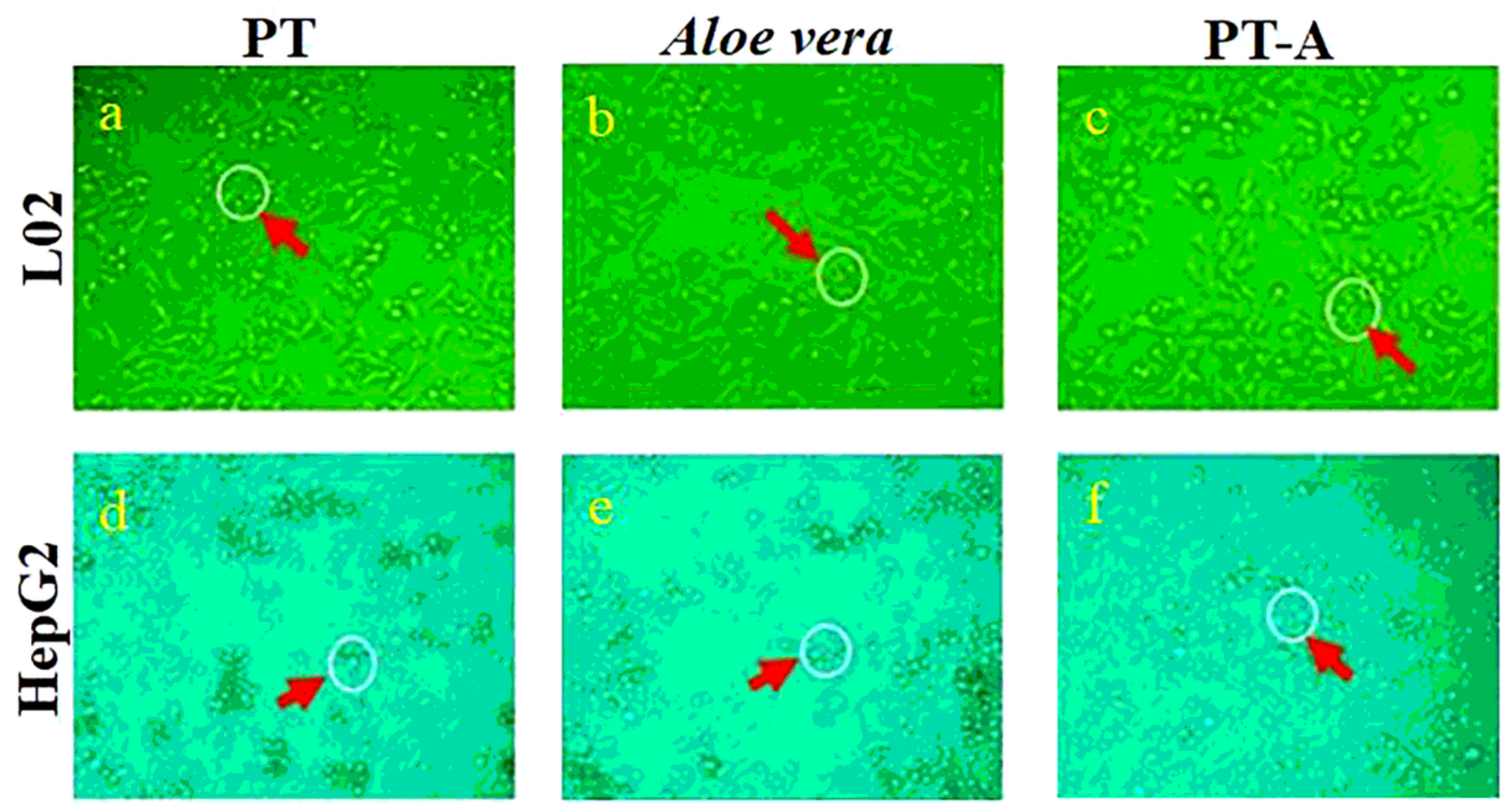

Figure 2

L02 \& HepG2 cells morphology at a concentration of $200 \mu \mathrm{g} / \mathrm{mL}$ after 8 Gy radiation pretreatment for 12 $h$ incubation (400x). 
A

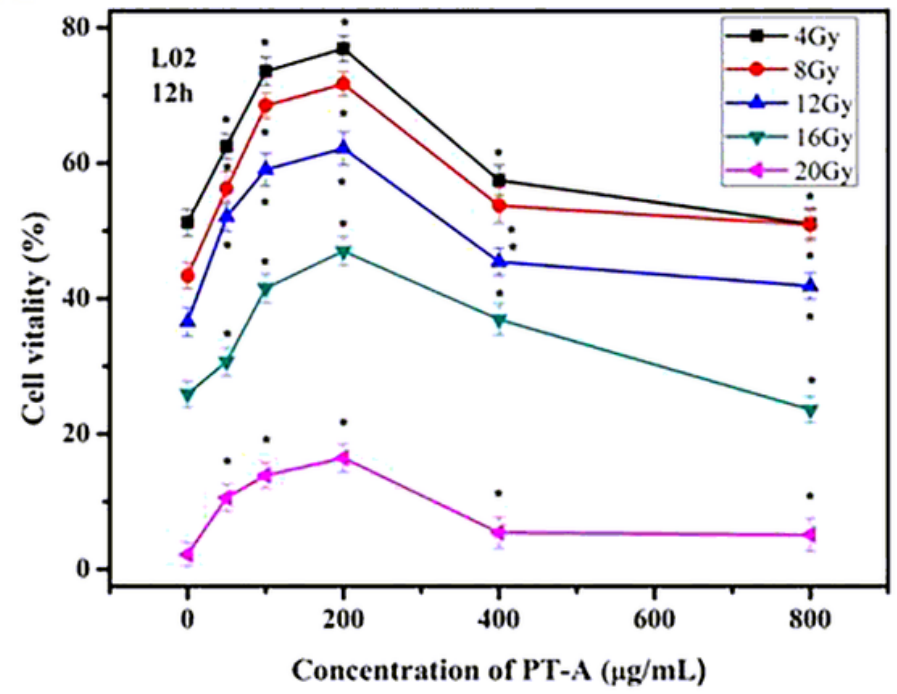

C



B

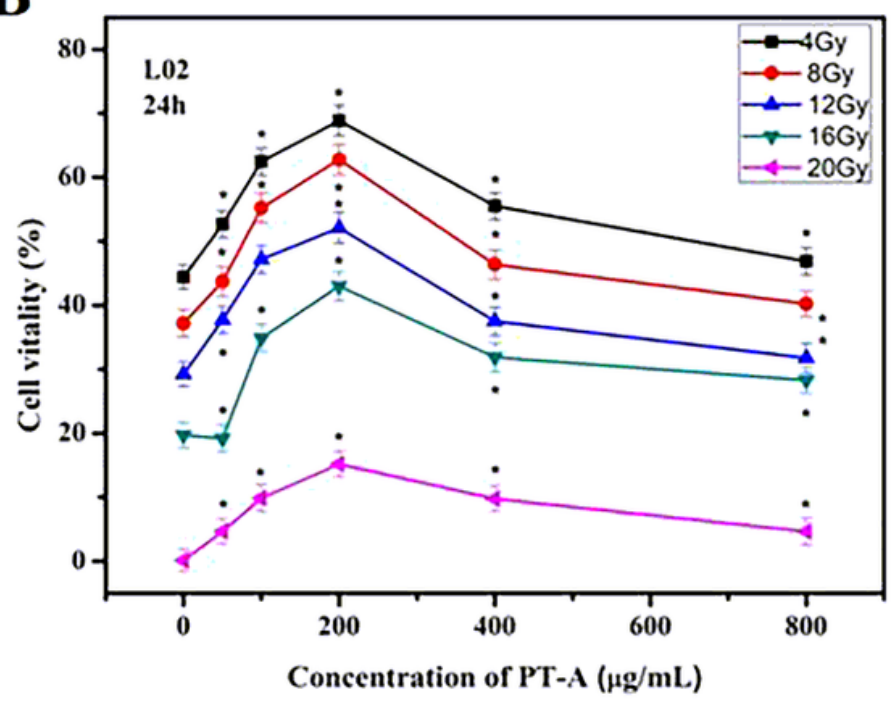

D

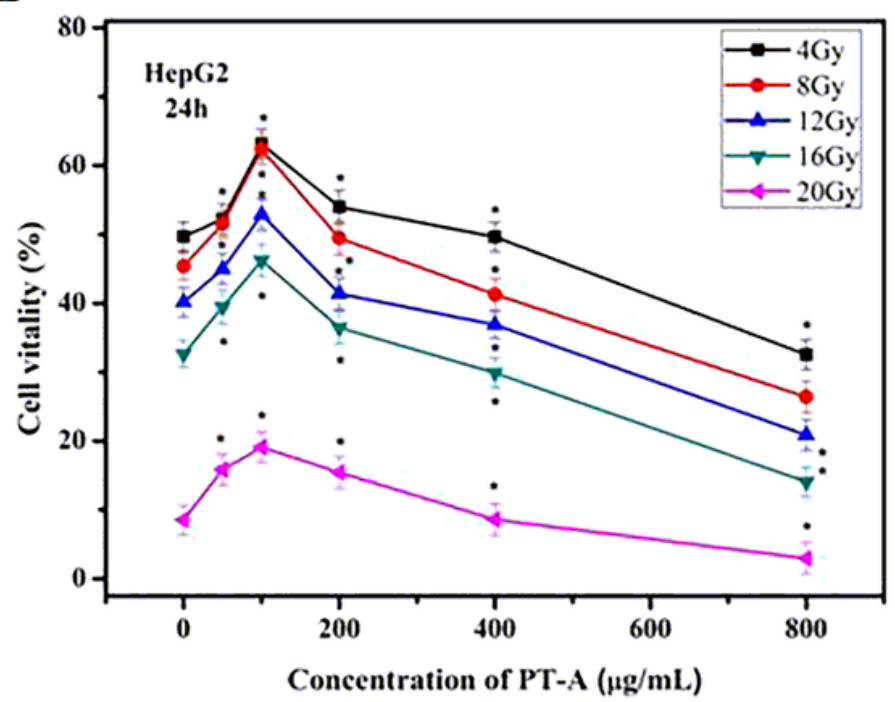

Figure 3

Cellular viability (\%) of PT-A with different concentrations of and different radiation doses 12 hours after radiation towards L02 cells or HepG2 cells (A \& C); Cellular viability (\%) of PT-A with different concentrations and different radiation doses 24 hours after irradiation towards L02 cells or HepG 2 cells (B \& D). All above values are presented as the median from analysis of three independent experiments and the error bars indicate standard deviation $(n=3, p<0.05)$. Symbol* represents $P<0.05$ vs. blank group (Concentration of $0 \mu \mathrm{g} / \mathrm{mL}$ ). 

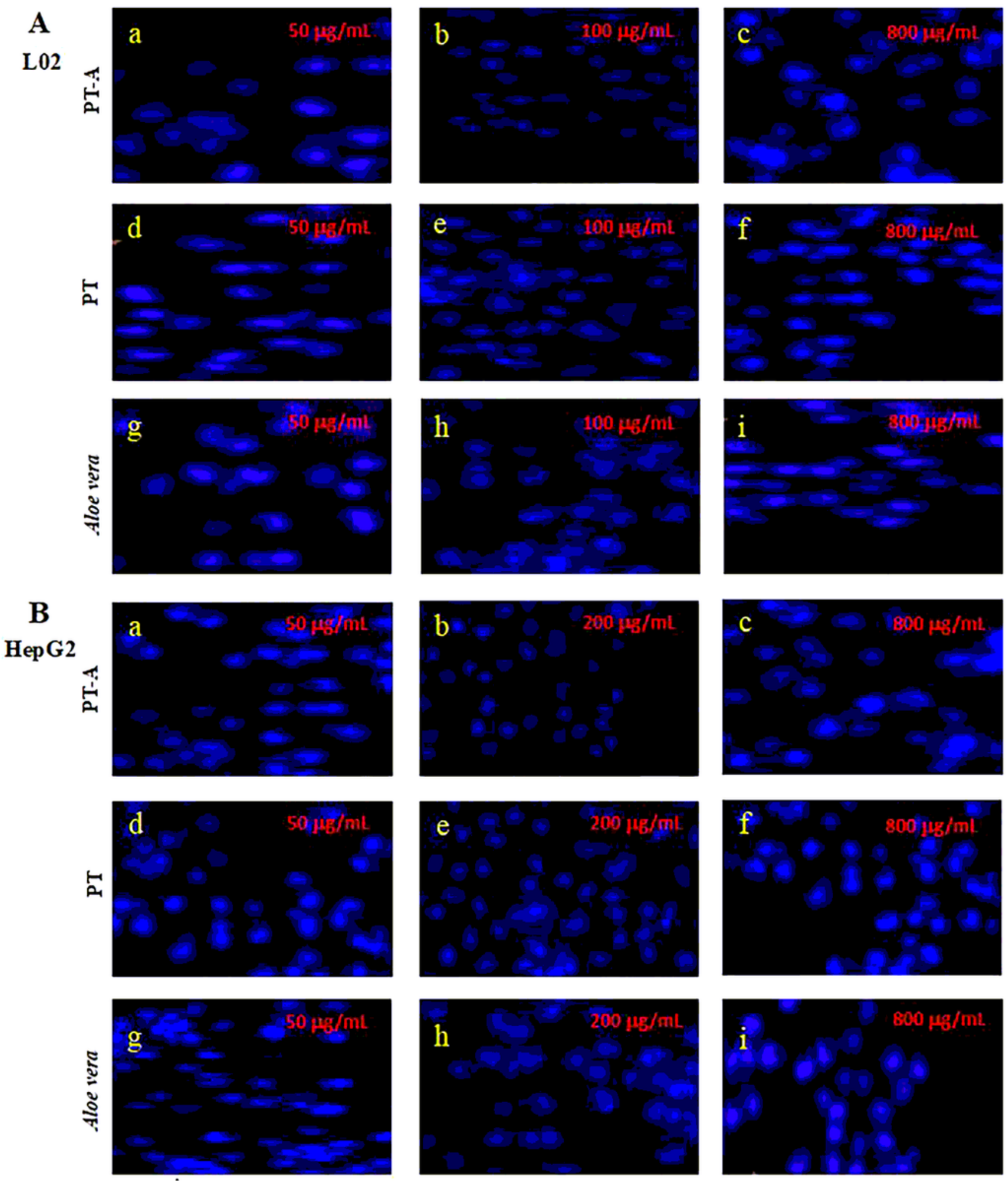

Figure 4

Hoechst 33258 fluorescent dyeing of L02 \& HepG2 cells pretreated with PT-A, PT, and Aloe vera materials for $12 \mathrm{~h}$ incubation after $8 \mathrm{~Gy}$ X-ray irradiation (A for L02 cells, B for HepG2 cells) (200x). 
$\mathbf{A}$

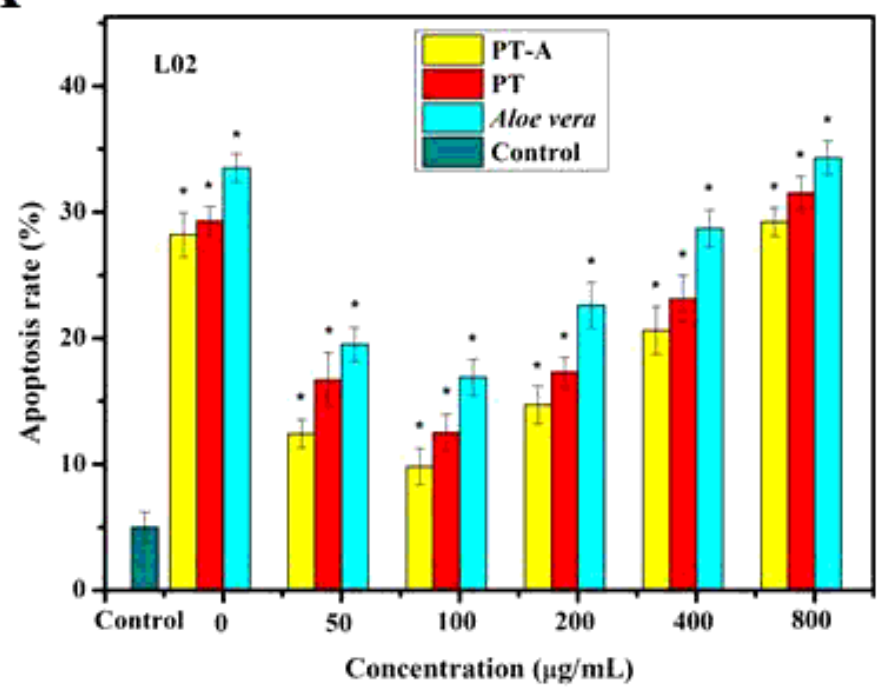

B

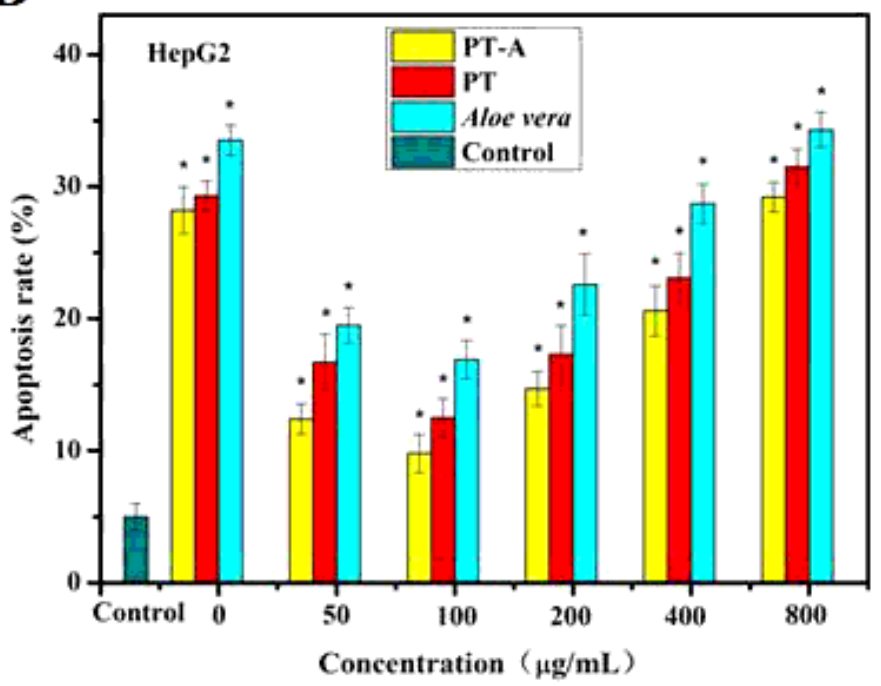

Figure 5

Flow cytometry to detect apoptosis rate of three materials in radiation experiments (A for L02 cells, B for HepG2 cells). All above values are presented as the median from analysis of three independent experiments and the error bars indicate standard deviation $(n=3)$, Symbol* represents $P<0.05$ vs. Control group.

A

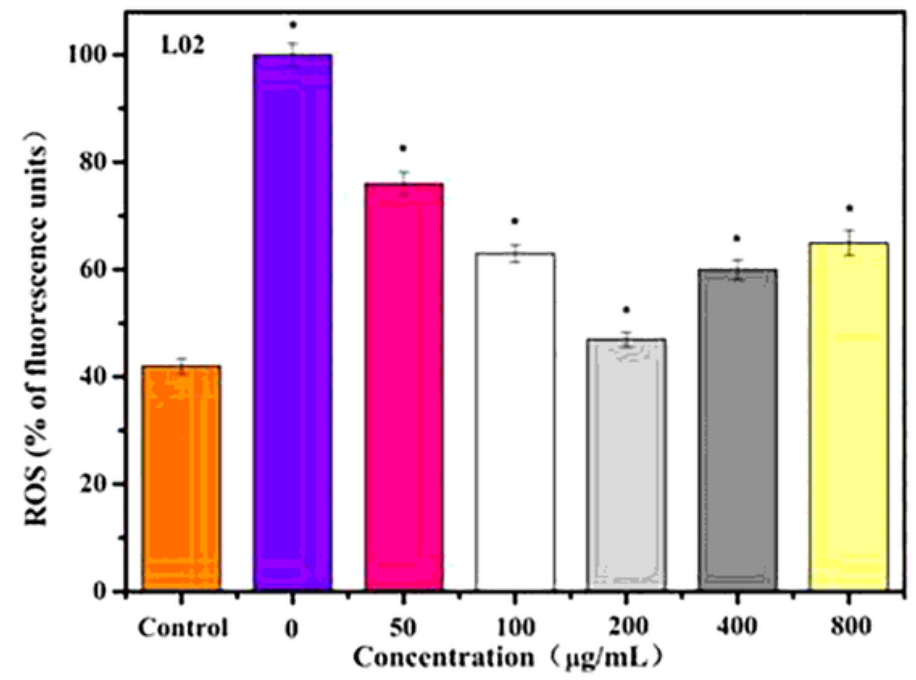

B

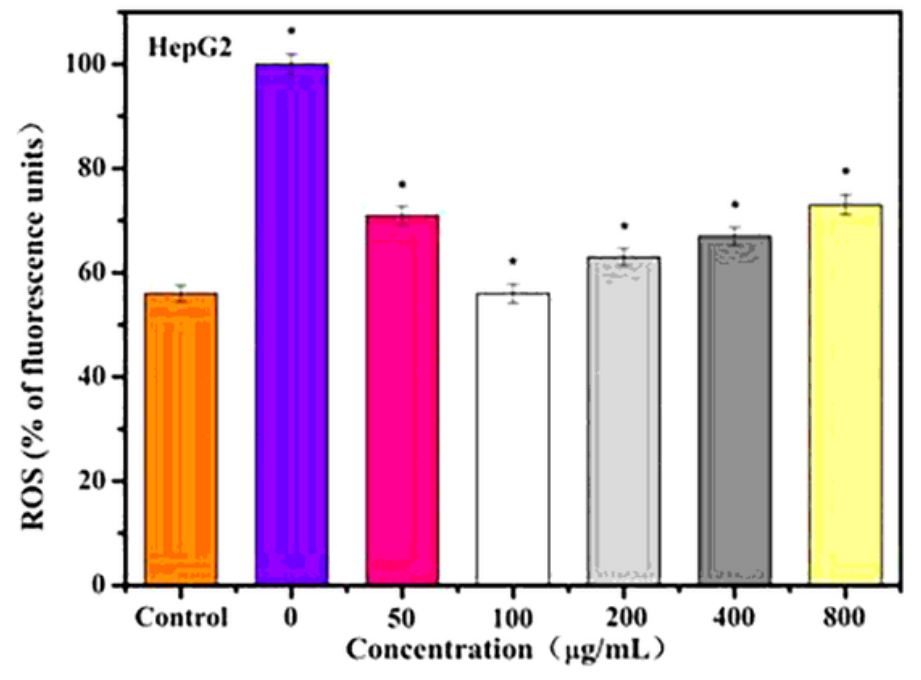

Figure 6

Scavenging effect of pretreatment of PT-A on ROS production in L02 \& HepG2 cells prior to 8 Gy irradiation (A for L02 cells, B for HepG2 cells). All above values are presented as the median from analysis of three independent experiments and the error bars indicate standard deviation $(n=3)$, Symbol* represents $\mathrm{P}<0.05$ vs. Control group. 